\title{
頭蓋内へ進展を認めた前頭洞囊胞例
}

\author{
浜 雄光 ${ }^{1)}$ - 越知 康子 ${ }^{2)} \cdot$ 芝野 忠寿 ${ }^{3)}$ - 浅野 純志 ${ }^{1)}$ \\ 安田誠 11 . 広村 弥生 1$)$. 久 育男 11
}

\section{A Case of Frontal Sinus Cyst with Intracranial Development}

\author{
Takemitsu Hama, Junji Asano, Makoto Yasuda, \\ Yayoi Hiromura and Yasuo Hisa \\ (Kyoto Prefectural University of Medicine) \\ Yasuko Ochi \\ (Maizuru Medical Center) \\ Tadahisa Shibano \\ (Shiga Hospital)
}

We report a 50-year old man with chronic sinusitis with frontal sinus cyst showing intracranial development. He complained of swelling in the medial angle of the right eyelid. Preoperative CT and MRI demonstrated a right frontal sinus cyst and ethmoid-maxillary sinusitis. The frontal sinus cyst compressed the right frontal lobe of the cerebrum, but no symptom was accompanied by frontal lobe impairment. Under general anesthesia, the frontal sinus cyst and sinusitis were accessed by intranasal ESS. We gently fenestrated the wall of the frontal sinus cyst with a microdebrider and drained the cystic component. The patient has been event free with no recurrence for 15 months postoperatively.

Key words : frontal sinus cyst, intracranial development, ESS, sinusitis

\section{はじめに}

慢性副鼻腔炎が関与する襄胞性病変の観血的アプロー チとしては鼻内法と鼻外法に大別される，以前は主に蝶 形骨洞や篩骨洞に対しては鼻内法が，上顎洞に対して鼻 外法と鼻内法が, 前頭洞には鼻外法が用いられてきたが, 最近の Endoscopic Sinus Surgery（以下，ESS）内視鏡下 副鼻腔手術の発達により, 鼻内法での症例が増えてきた。 しかしながら前頭洞病変に対しては換気排泄路が閉塞し やすく, また時に頭蓋内へ病変が進展する症例もあるこ とから, 開放だけでなく摘出, 充填, 再建等の各種アプ ローチ法が試みられている。
今回われわれは慢性副鼻腔炎に合併し頭蓋内一進展し た前頭洞囊胞に対し，ESS のみによる開放術を行い，術 後に頭蓋内合併症や再発を認めていない 1 症例を経験し たので，頭蓋内進展症例に対するアプローチ法の選択を 中心に若干の文献的考察を加えたので報告する.

\section{症例}

症例 : 50 歳, 男性.

主訴：右前額部加ら内眼角への腫脹.

既往歷：副鼻腔炎手術歴や頭部外傷歷なし。

家族歴：特記すべき事項なし。

1）京都府立医科大学耳鼻咽喉科学教室

2）国立舞鶴医療センター耳鼻咽喉科

3）国立滋賀病院耳鼻咽喉科 
現病歴：約 20 年前に副鼻腔炎を指摘されまた以前よ り鼻閉の自覚はあったが放置していた。眼症状（複視， 視力低下) や脳神経症状の自覚はなかったが, 平成 15 年 春頃より右前額部から内眼角への腫脹を認め同部を圧迫 すると鼻腔内一何か流れる感じもするとのことで，平成 15 年 10 月 17 日に前医病院を受診した。前医で CT・MRI を施行され頭蓋方向一進展する囊胞性病変が考えられた ため, 平成 15 年 11 月 19 日当科紹介受診された. 慢性副 鼻腔炎に合併し頭蓋内一進展する右前頭洞囊胞が考えら れたため加療目的にて平成 16 年 1 月 8 日当科入院となっ た.

現症：顔面の所見では右前額部から内眼角にかけて直 径 $2.5 \mathrm{~cm}$ の腫脹を認めたが弾性軟で圧痛はなかった。 ま た眼球運動制限や脳神経症状も認めなかった。鼻内所見 では両側に鼻ポリープを認め，右側ポリープの一部は表 面軽度不整であった。

術前検查：画像所見では, CT で右前頭洞の前壁と後 上方にかけ骨欠損を疑う部分が存在し，また上顎洞・篩 骨洞には軟部組織陰影の充満を認めた（図 1).MRI では 右節骨洞・前頭洞办ら前頭葉を後方に圧排する形で $\mathrm{T} 1$ 強調像でやや低信号, T2 強調像で高信号の病変を認め,
囊胞性病変が考えられた（図 2)。上顎洞・篩骨洞につい ては慢性副鼻腔炎と考光矛盾しないが内部信号がやや多 彩な領域を認めた。右鼻ポリープの一部が表面軽度不整 (乳頭腫様) であったため, 生検を行ったところ, 病理報 告で乳頭腫疑いであったため, 左側を含め両側の鼻ポ リープを再度生検した。再検の報告は核多層化を伴う上 皮肥厚が存在するが，悪性所見は認めないとの結果で あった．鼻汁培養検查については菌の検出を認めなかっ た。 以上の結果より，慢性副鼻腔炎に合併し頭蓋内一進 展する右前頭洞囊胞と診断した。

治療：現症や画像所見より，ESSによる鼻内ドレナー ジのみで囊胞性病変に対応可能と判断したが，術中や術 後に髄液漏や頭蓋内合併症を生じる可能性も低いが考え られたため, 術前に脳神経外科にコンサルトしておき, 脳外科的処置が必要な場合に備えた。

手術：平成 16 年 1 月 9 日全身麻酔下にマイクロデブ リッダーも併用し両側 ESS を施行した。 上顎洞・篩骨洞 の副鼻腔炎に対して ESS は定型的に施行したが，篩骨洞 については非常に蜂巣の骨化が高度であった. 右 ESS で は骨化した前篩骨洞を開放したところ，囊胞壁と考えら れる部分を認め，さらにその部位を鼻前頭管方向へ開放

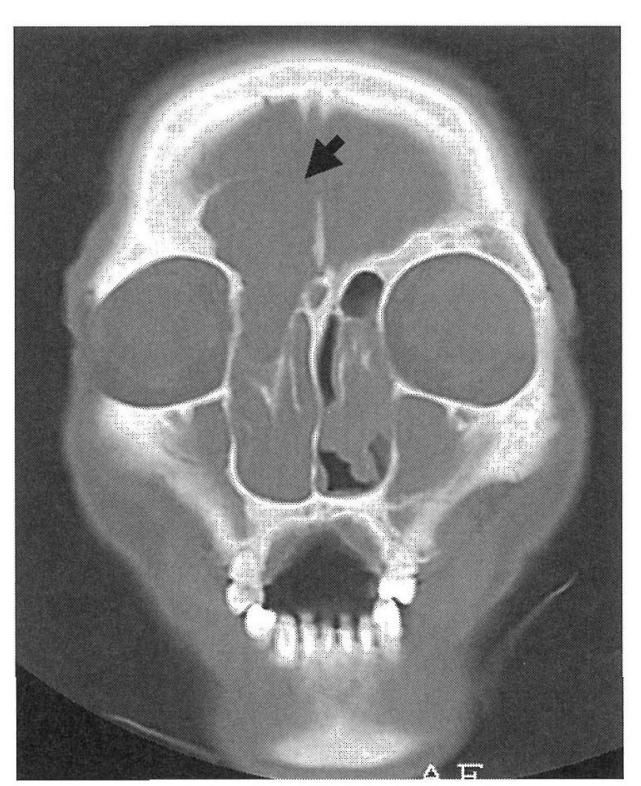

a

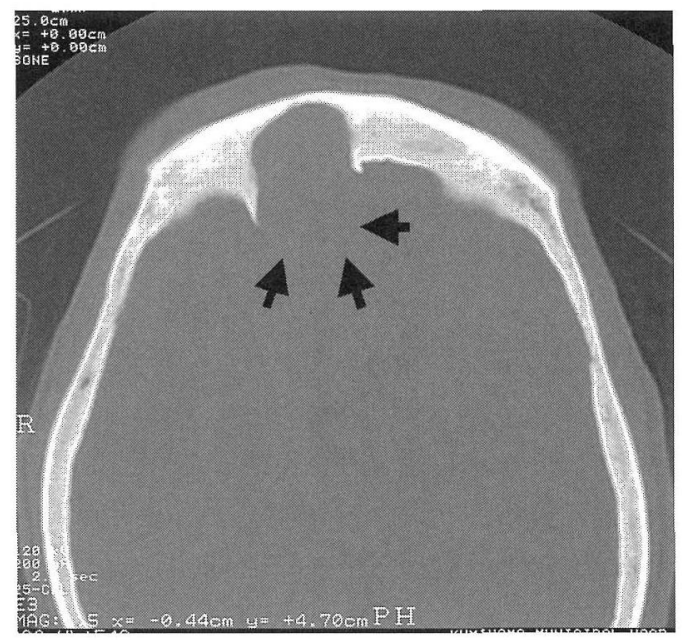

b

図 1 術前 CT

a. CT 冠状断 b. CT 軸位断

CT では右前頭洞の後上方にかけ突出するように骨欠損を疑う部分が認められる (矢印). 


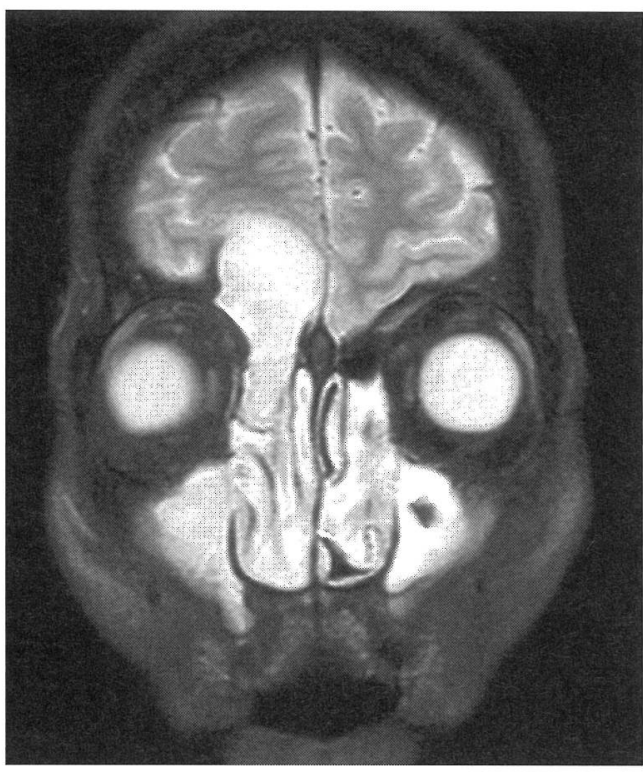

a

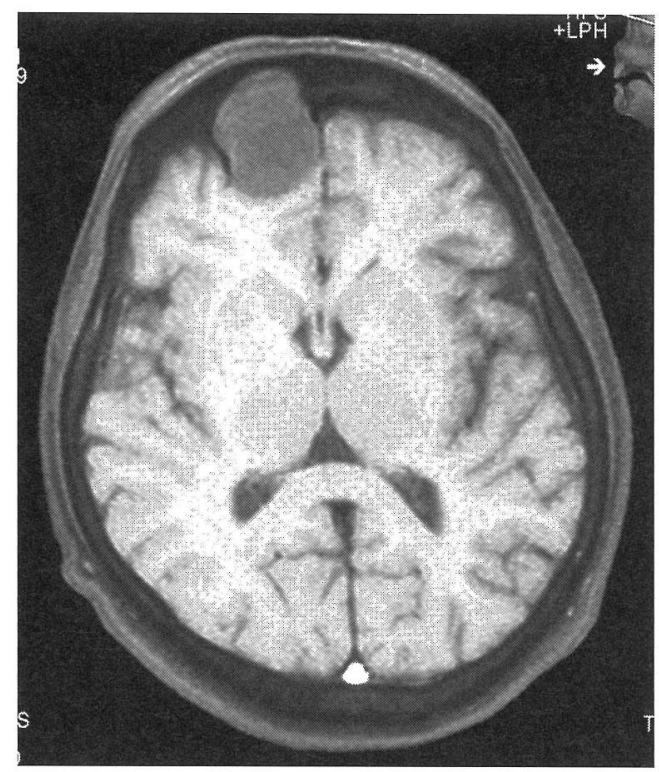

b

図 2 術前 MRI

a. MRI 冠状断（T2W1） b. MRI 軸位断（T1W1）

MRI では右穊骨洞・前頭洞から前頭葉を後方に圧排するように, T1 強調像でやや低信号, T2 強調像で高信号の囊胞性病変を認め た.

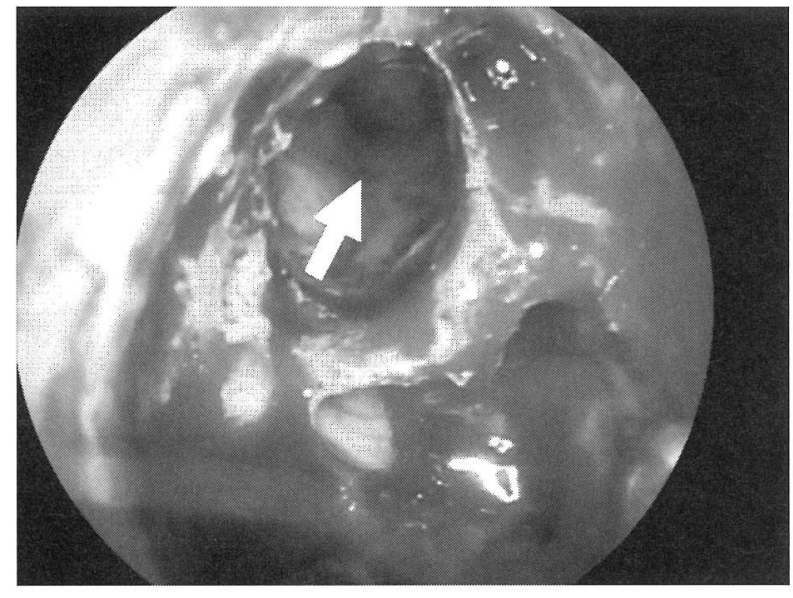

a

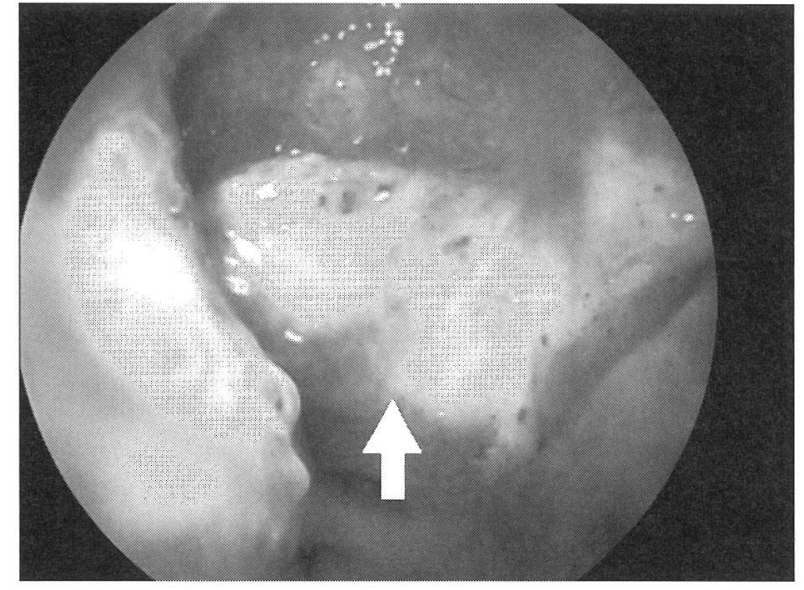

$\mathrm{b}$

図 3 術中所見

a. 卒胞壁開空部 b. 前頭洞後壁

骨化した右前䇥骨洞を開放してゆくと囊胞壁と考えられる部分が存在し，その部位を鼻前頭管方向へ開放すると黄白色で漿液性 の膿汁排出が多量にみられた (図 a の矢印)。同部をさらに拡大し，上方を 70 度斜視鏡で観察すると，右前頭洞後壁の硬膜相当 部分と考えられる部分を認めた (図 bの矢印).

すると黄白色で漿液性の膿汁排出が多量にみられた。上 方を 70 度斜視鏡で観察すると, 右前頭洞後壁の硬膜相当 部分は軽度の拍動を認めたが，術中髄液漏や硬膜の突出
徴候も認めなかったため（図 3），ESS のみで鼻内ドレ ナージは十分と考光，Killian 外切開や充填再建等は施行 せず手術を終了した。 


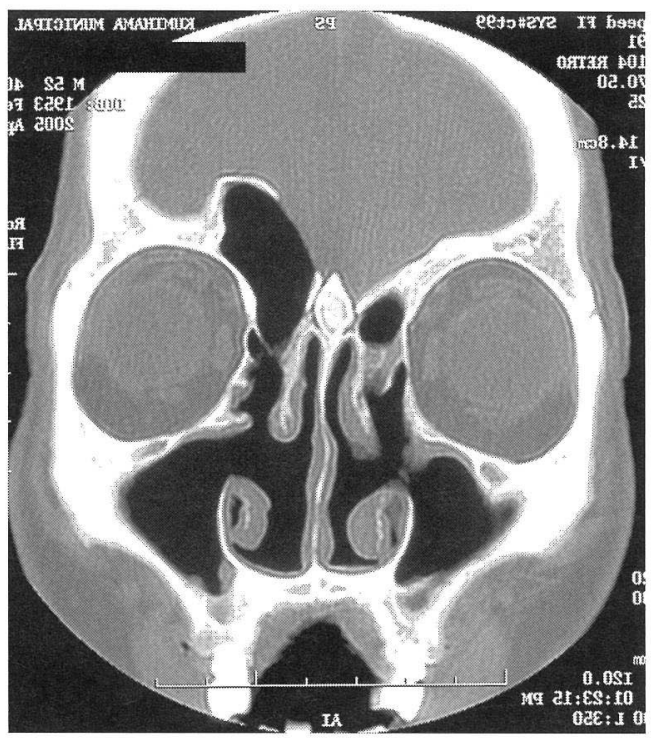

a

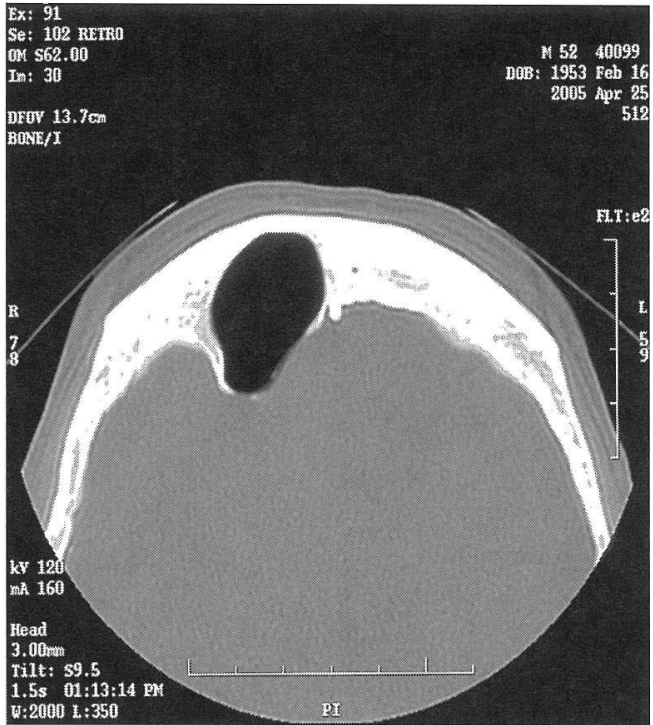

b

図 4 術後 CT

a. CT 冠状断 b. CT 軸位断

術後 15 カ月目の CT では右前頭洞は空洞性治癒をして㧍り，また鼻腔への排泄路も開存し，頭蓋内へ進展した前頭洞上後壁部分 も術前と比較し変化はほとんど認めなかった。

病理組織：術中迅速標本では鼻ポリープで乳頭腫や悪 性所見は認めず，永久標本でも組織は慢性副鼻腔炎のみ の結果であった。

術後経過：術後にも脳神経症状，髄液漏等の症状は認 めず，また術後 5 日目の CT でも前頭洞方向への脳実質 の突出はなか⿰た。．また退院後は外来で鼻処置・マクロ ライド療法を 3 力月施行した。

術後画像 : 術後 15 力月目の CT では右前頭洞は空洞性 治瘾を呈しており，頭蓋内一進展した前頭洞上後壁部分 も術前と比較し変化はほとんどみられなかった。また震 胞の再発および排泄路の閉塞も認めず，他の副鼻腔も含 めて術後所見は非常に良好であった（図 4).

\section{考察}

鼻科手術における内視鏡の発達により，副鼻腔疾患に 対してESSを適応する症例が多くみら机るようになって いる。しかしながら他の副鼻腔病変に比較し, 前頭洞病 変に対しては鼻前頭管から鼻腔への換気排泄路が閉塞し やすく，また時に頭蓋内一病変が進展し，まれに重篤な 症状を呈する症例もあり, 鼻内一の開放1) だけでなく囊 胞壁の摘出, 脂肪・骨パテ・セラミックの充填, 筋膜や
筋皮弁による再建等の各種アプローチ法も行われてい る2) 4).

そこで今回前頭洞囊胞が頭蓋方向へ進展していた症例 に対して，鼻内への開放のみか再建充填まで行ったかで 文献的に分けて検討してみると,再建充填した症例では, (1)過去の外傷により脳膿瘍等の頭蓋内合併症を起こし, 鼻腔と前頭洞を経て脳への明らかな感染経路が考えられ たもの 5), (2)囊胞㤁前頭洞から眼窩や側頭部方向の他領 域へ進展したもの 6$)$, (3)囊胞壁と硬膜が広範囲に癒着し, 明らかな拍動が前額部から触れるもの ${ }^{7)}$ 等が挙げられ た。このような症例では基本的に囊胞壁を全摘し，脂肪 の充填, 骨パテやセラミックによる硬性の充填となる再 建，筋膜や筋皮弁による軟性の充填再建等の各種方法が 行われている。また，再建充填しなかった症例では，前 述のような状態でなく(1)鼻内からで十分開放可能で術後 も再閉塞の可能性が低いもの ${ }^{8)}$, (2)骨欠損があっても, 脳 ヘルニア等の可能性が非常に低い9)，(3)囊胞の緩徐な頭 蓋内一の進展が考えられたもの10)等が挙げられた。

過去の副鼻腔手術歴の有無について検討してみると， 再建充填の有無にかかわらず，どちらのグループでも手 術歴の有るむのと無いものがあり，偏りはみられなかっ 
た ${ }^{5)}$ 11). また骨欠損の有無についても前頭洞から眼窩 や側頭部方向の他領域へ進展例を除くと, 前頭洞上後壁 の骨欠損が大きくても再建充填していない症例も多 <9) 11), 手術歴の有無や骨欠損の有無は再建充填の方針 を決定するための一次的要素でなく二次的要素と考えら れた。

今回われわれが経験したのは，手術歷がなく慢性副鼻 腔炎に合併し頭蓋内方向へ進展した右前頭洞囊胞の症例 であった，術前画像所見では，CT・MRI で右前頭洞の前 壁と後上方にかけ骨欠損を伴い前頭葉を後方に圧排する 囊胞性病変が考えられた。 また霊胞は鼻前頭管から篩骨 洞方向へも進展しており，ESS にて穊骨洞から鼻前頭管 方向を開放するだけで大きく排泄路が作製され，ドレー ン挿入等も不要と考えられた。頭蓋内一進展した前頭洞 後壁部分の処置については, 上述のような検討を行い, (1)脳膿瘍の合併や頭蓋内一の感染はない, (2)囊胞は前頭 洞以外の他領域へ進展していない, (3)外部から明らかな 拍動は触れない, (4)鼻内からで開放可能で再閉塞の可能 性が低い，(5)緩徐な頭蓋内への進展で前頭洞後壁はある 程度の強度を保っている可能性が高く, 骾液漏等の可能 性は低いと考え, ESS のみで再建充填は行わず対応でき ると考えた。 そして観血的治療としては，全身麻酔下に ESS を行い, 囊胞に対しては ESS で鼻腔内下方より開放 し，前頭洞後壁部分は触らず，万一洞後壁から髄液漏等 を生じたばあいは外切開（Killian 法）を行い洞内の充填 等を考慮した。

実際の術中所見でも，前頭洞後壁の硬膜相当部分は䯣 液漏もなく, わずかな拍動を認めるのみで，また術後 5 日目と術後 15 力月目の CT でも術前と比較し変化はほと んどなく, 本症例では骨欠損部分はある程度の強度を 保っていると思われた。髄液漏や頭蓋内感染症のように 可能性は低くても一度発症すると重篤な疾患となる合併 症は念頭に置く必要はあるが，前述のような症例では外 切開や再建充填は行わず低侵襲のESS のみで対応可能で あったと考えられた。

\section{まとめ}

1. 頭蓋内へ囊胞進展を認めた慢性副鼻腔炎の 1 症例を 経験した.

2. 本症例は鼻内開放手術のみで再建充填は施行せず,
術後に脳神経症状・再発・閉塞等は認めなかった。

3. 頭蓋方向へ進展した症例でも，再建充填せず ESS のみで対応可能な症例も多いと考えられた。

4. 手術歴の有無や骨欠損の有無は再建充填の方針を 決定するための一次的要素でなく二次的要素と考えられ た.

$$
\text { 付 記 }
$$

本論文の要旨は, 第 92 回日本耳鼻咽喉科学会京滋合同地方部 会 (平成 17 年 12 月 17 日，京都）に㧧いて口演した.

\section{参考文献}

1) Kennedy DW, Josephson JS, Zinreich SJ, et al. : Endoscopic sinus surgery for mucoceles: a viable alternative. Laryngoscope $99: 885 \sim 895,1989$.

2) Knauff HA : Single-stage frontal sinus obliteration: bone graft plastic repair. Arch Otolaryngol $78: 707 \sim 714,1963$.

3) Weber R, Draf W, Keerl R, et al. : Osteoplastic frontal sinus surgery with fat obliteration: technique and long-term results using magnetic resonance imaging in 82 operations. Laryngoscope $110: 1037 \sim 1044,2000$.

4) Parhiscar A and Har-El G : Frontal sinus obliteration with the pericranial flap. Otolaryngol Head Neck Surg 124:304 307, 2001.

5）浜口幸吉, 浜口富美, 坂倉康夫, 他：頭蓋内合併症をきた した前頭洞囊胞 2 症例. 耳鼻・頭頸外科 63:285 289, 1991.

6) 白馬伸洋, 佐伯忠彦, 兵頭政光, 他: 開頭術を要した側方 伸展型の前頭洞囊胞例. 耳鼻臨床 $89: 455 \sim 460,1996$.

7）緒方憲久, 湯本英二：症例からのアプローチ 前頭洞囊胞 と鼻副鼻腔手術. JOHNS 18 : 1549 1554, 2002.

8）吉川 衛, 石井正則, 吉田 茂, 他：内視鏡下鼻内手術で 開放しえた巨大な前頭洞囊胞. 耳鼻展望 $42: 505 \sim 509$, 1999.

9）出口浩二, 西元謙吾, 松根彰志, 他 : 頭蓋内へ進展した巨 大な多発性前頭洞囊胞の一例. 日鼻科会誌 $41: 137 \sim 142$, 2002.

10）多田靖宏, 小川 洋, 桑畑直史, 他 : 頭蓋内進展を呈した 前頭洞篩骨洞囊胞例. 耳鼻臨床 $98: 291 \sim 296,2005$.

11）酒井章博, 上野ゆみ, 横山道明, 他：頭蓋へ進展した原発 性巨大前頭洞袈胞例. 耳鼻臨床 $98: 847 \sim 851,2005$.

原稿受付: 平成18年 8 月 17 日 原稿採択：平成19年 1 月 12 日 別刷請求先: 浜 雄光 厂 602-8566 京都市上京区河原町通広小路上る梶井町 465

京都府立医科大学耳鼻咽喉科学教室 